\title{
The Effect of Different Types Organic Mulching on the Growth and Yield of Brassica rapa subsp. Chinensis
}

\author{
Tibane Meluleki Adrian* \\ Tshwane University of Technology, South Africa \\ *Corresponding Author: Tibane Meluleki Adrian, Tshwane University of Technology, South Africa.
}

Received: August 17, 2019; Published: October 30, 2019

DOI: 10.31080/ASAG.2019.03.0702

\begin{abstract}
The study was conducted in a Greenhouse at Tshwane University Nursery owned by the TUT (Department of Horticulture) to determine the best mulching types on growth and yield of B. rapa subsp Chinensis. Five mulching materials (Peachpips, Wood shavings Coffee grounds, Newspaper, Control fertilized with Multifeed) and control (no treatment) were used to test the effect of mulching on growth and yield of B. rapa subsp. Chinensis seedlings. The experiment was laid out in Completely randomized block design with three replicates. Seeds of B. rapa subsp. Chinensis were sown in mid-May and two weeks after seedling have emerged some were then transplanted. Fertilizers were applied after one week after transplanting. Data was collected once a week on plant height $(\mathrm{cm})$ and number of leaves but irrigating twice a week for duration period of 6 weeks. At harvest data was collected again on plant height $(\mathrm{cm})$, number of leaves, and root length (cm). At harvest. results show that fertilizer treatments did not significantly differ from the control, however seedlings applied with Multifeed and Vita veg fertilizer resulted with the highest average number of leaves. Seedlings applied with LAN had tall roots followed by control, while peachpips and Control resulted with short roots This is a quantitative study undertaken with statistical tests.
\end{abstract}

Keywords: Brassica rapa subsp. Chinensis; Mulching; South Africa

\section{Introduction}

Brassica rapa subsp. Chinensis well-known edible crop in South Africa though it is not available in local supermarkets [1]. Although Chinese cabbage (Brassica rapa subspecies Chinensis) is not native to South Africa, it has been adopted and indigenized because of its adaptation to the environment, the crop is mostly produced by small scale farmers in South Africa [1].

The Chinese cabbage is produced mainly in the semi-arid, dry summer, subtopic rainfall climatic zone of China. Brassica rapa subsp. Chinensis has not been developed in South Africa yet [2]. Optimum production has not been achieved because of its difficult agronomic characteristics (maturity and height, etc), decline in soil fertility and lack of techniques for growing the crop in both nursery and field The leaves of B. rapa are used in cooking [3]. The interest in Brassica rapa subsp Chinensis globally concise with the demand for nutrient rich crops.

It is believed that Brassica rapa subsp Chinensis consist of $95 \%$ water content and a very high nutrient content, it is actually ranked second in the 41 top rated food crops for the benefit of human body and consumption.

Genus Brassica is one of 51 genera in the Brassicaceae family containing 37 different species, it is regarded as one of the most economically important genus within this tribe (Brassicaceae and Cruciferae) [4]. The genus originate from Asia and China, and 2000 years ago it has been introduced to most part of the world [5]. In South Africa the crop is used by means of boiling in soups and still used as fresh for salads or stir fried in dishes.

The Brassica rapa subsp Chinensis is propagated from seed. The seed is very small in a black-grey color [2].

The aim of the study was to find materials which are possible organic and nonorganic fertilizers that can improve the yield of the Chinese cabbage. which is used to improve the nutrient content in plants. The study intended to find out the feasibility of growing Brassica rapa subsp Chinensis on the different organic and nonorganic fertilizers.

\section{Significance of the study}

Using organic mulches has great advantage. It conserves moisture which means frequent fertilizing is not necessary anymore. It prevents growth of weeds as well as soil toxicity. The application of more organic fertilizers can become a soil enhancer too. These organic mulching materials are accessible to those who grow vegetable, but it can also be available to commercial growers. Nonorganic mulching also influence the growth of edible vegetables.

\section{Scope and Limitations of the study}

The researcher only observed the feasibility of the following material peachpips, wood shavings, Newspaper, and Coffee grounds. No other plants besides of Brassica rapa Chinensis will be observed. The study is attempted to answer the following question. 
Research question

- $\quad$ Are the following organic and nonorganic fertilizers (Woodshavuings, Peachpips, coffee grounds and Newspaper) feasible as suitable organic mulching to grow the Chinese cabbage?

- What is the correct or most suitable growth media for the Chinese cabbage.

Problem statement

Optimum production of Brassica rapa subsp. Chinensis has not been reached because of its difficult agronomic characteristics and decline in soil fertility. Commercial growers and stallholder farmers often think of over fertilizing to produce more yields without evaluating the crops requirements and propagation and cultural practices. In terms of fertilizer sowing and fertilizer program, no clear media and suitable fertilizer has been yet determined for the growth and maximized yield of the Chinese cabbage in South Africa Particularly without having adverse effect on the environment or on the species and the availability to the population to have and the revenue generated by smallholder farmers Instead, it is the intangible qualities that arguably shape our understanding of over fertilizing, overwatering and damaging the environments. Brassica rapa subsp Chinensis needs a lot of water and nutrient content and South Africa is a water scarce country. Mulch can be used to prevent water loss but the effect on the growth of Brassica rapa subsp Chinensis in not known.

\section{Aim of the study}

To determine the best mulching types for the maximum growth and yield of Brassica rapa subsp. Chinensis.

\section{Objectives}

The objective of the study is to evaluate the different organic mulching to determine the best mulching types for the maximum growth and yield of Brassica rapa subsp. Chinensis.

\section{Hypothesis}

Application of organic mulching will have an effect on growth and yield of Brassica rapa subsp. Chinensis.

\section{Justification of the study}

The study of planning and management of leafy crop production is justified on various grounds.

First, the field of non-heading crops planning and management is under-researched with scarce literature on Chinese cabbage public in South Africa but it is potentially revelatory propagation for intrepid researcher.

\section{Research audience}

According to (Monle, 2001) research is best concerned as the process of arriving at dependable solutions to problems through the planned and systematic collection of data. It is a most important tool of advancing knowledge for promoting process and for enabling a person tolerate more effective to his/her environment, to accomplish his/her purposes and to resolve conflicts. This statement implies that researchers work in a vacuum. They have obligations to study a specific phenomenon, record data and communicate their findings under controlled greenhouse environment groups or individual members of society who have an interest in the issue under investigation.

\section{The possible audience for the present study is as follows}

- $\quad$ Researchers with an interest on this field as well as Policy makers on this field.

\section{The structure of the present study}

The research report is divided into five chapters. The first chapter is representing the background and justification of the study. It also explains the objective, the hypothesis and the research problem. Chapter two is the literature review on the Brassica rapa subsp. Chinensis and types of organic and nonorganic fertilizers that are currently used in the industry. Chapter three is focusing mainly on the material and methods used to answer the objective. Chapter four is the results and discussion on the results obtained during and after the experiment. Chapter five is the conclusion and future recommendations.

\section{Literature Review}

\section{Brassica rapa subsp Chinensis}

Brassica rapa subsp Chinensis is a non-heading type of a cabbage, it is an annual, erect, and leafy vegetable that can grow up to $15 \mathrm{~cm}$ to $30 \mathrm{~cm}$ tall (Figure 1) [6]. According to Tsunoda, Hinata and Gomez-Campo [4], it belongs to the Brassicaceae family which is a very diverse family that includes many economically important oilseed, forage, roots, ornamental and vegetable crops.

Chinese cabbage is a remarkable vegetable for high yield, ecological plasticity, and valuable biochemical composition, having a high water content, low caloric value, containing high quality protein, carbohydrates, fiber, vitamins, and minerals [7]. Chinese cabbage as well as other crucifer species, is characterized by the high ability to adapt to a wide range of habitats and Growing conditions [8].

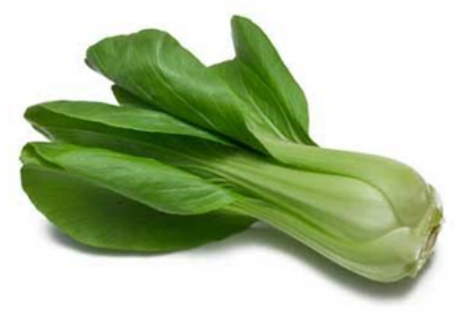

Figure 1: Matured Brassica rapa subsp. Chinensis (http//:www.B.rapa/Chinensis. crops/html). B. rapa subsp. Chinensis.

\section{Plant morphology of Brassica rapa subsp. Chinensis}

Brassica rapa subsp. Chinensis has leaves that are spirally arranged with a heavy midrib in the middle like a rosette, leaves are 
light or dark green and oval or egg shaped with slightly serrated margins (Figure 2) [9].

According to Indrea., et al. [10] Chinese cabbage has a shallow root system, which limits its ability to take up water and nutrients from a deeper soil profile and it also produces significant leaf mass in a relatively short vegetation period, the nutritional demand is very high [11].

The inflorescence of Brassica rapa subsp. Chinensis plant is a terminal umbel-like raceme which can grow up to $60 \mathrm{~cm}$ long [12]. The plant has slightly fleshy stems with the diameter of $0.5-1 \mathrm{~cm}$ and $15-20 \mathrm{~cm}$ long in length.

\section{Importance and uses of Brassica rapa subsp. Chinensis}

Brassica rapa subsp. Chinensis is used as an edible plant for human consumption. The Food and Agricultural Organization (FAO) [13], cabbage has been identified as one of the top twenty vegetables and important source of food globally. It helps reduce blood pressure, is high in potassium, and can fight anemia and fatigue because of its high content of iron which is essential for the blood to produce hemoglobin, and it is also very rich in antioxidants and keeps the eyes healthy.

\section{Propagation and Growth requirements of Brassica rapa subsp Chinensis}

According to Dept. of agriculture, forestry and fisheries [2] Brassica rapa subsp. Chinensis is propagated from seed. According to Deng, Heap and Klein [14] Chinese cabbage is an important vegetable crop, however an efficient procedure for in vitro vegetative propagation is useful for commercial production, therefore an effective plant tissue culture technique have been developed for propagating Brassica, including in vitro regeneration of Chinese cabbage from axillary buds of headed plants and shoot tips from seedlings.

Chinese cabbage is a cool, season crop and need adequate water throughout the growth period. It grows best normally in winter and should be watered for good yields for maximum production and mineral gain [15]. Chinese cabbage grow well in cooler periods in the winter season of the year and it also prefer an average of $18^{\circ} \mathrm{C}$ to $22^{\circ} \mathrm{C}$ during the early growth [16]. According to Duke [5], Chinese cabbage is grown successfully on range of soil types ranging from sandy soil to much heavier textured soils. Soils that are well drained, possess good structure, fertility and water holding capacity usually produce a satisfactory crop of the Chinese cabbage.

\section{Plant nutrients}

Fertilizer is a substance applied in the soil to increase crop yields by providing one or more elements that are essential plant nutrients [17]. Fertilizer consists of two types such as Organic and nonorganic: Organic refer to fertilizers that has gone through minimal processing, where nutrients are still found in their natural forms, e.g. Vita veg. Nonorganic refer to fertilizers that are synthetic or artificial and manufactured from petroleum products, e.g. Limestone Ammonium Nitrate (LAN) and Multifeed.
Previous studies on Fertility program or enhancement on Chinese cabbage

Studies show that there have been experiments done to evaluate the most suitable organic mulching material as to grow the Chinese cabbage. A study was conducted using chicken manure and Cattle chicken manure were each applied at the rate of $3 \mathrm{t} \mathrm{ha}^{-1}$ (air-dry) after ploughing and incorporated in the soil during disking. At planting, the fertiliser mixture 2:3:2 (22) was applied in the planting furrow at the rate of $624 \mathrm{~kg} \mathrm{ha}^{-1}$. LAN $(28 \% \mathrm{~N})$ was bandplaced at the rate of $150 \mathrm{~kg} \mathrm{ha}^{-1}$ when the plants had reached the eight-leaf stage and again one week later at the rate of $100 \mathrm{~kg} \mathrm{ha}^{-1}$ . The resulting total application of $213 \mathrm{~kg} \mathrm{~N} \mathrm{ha}^{-1}, 99 \mathrm{~kg} \mathrm{P} \mathrm{ha}^{-1}$ and $75 \mathrm{~kg} \mathrm{~K} \mathrm{ha}^{-1}$ were within the optimum range for dabadaba identified by Van Averbeke., et al. (2007b). The comparison between the two trials proves that one need to incorporate the application of different fertilizers on the correct time and allow enough time to harvest. Fertilization. Chinese cabbage is a crop that should have an uninterrupted growth. Any delay in growth will encourage the plants to prematurely form a small head that is of no value. In order to avoid this, the soil should be high in organic matter so that it will hold a lot of moisture. It must also be very fertile.

\section{Irrigation and water requirements}

For optimum growth and leaf yield, Chinese cabbage requires the soil water content in the upper part of the profile to be maintained at or close to field capacity and this required the crop to be irrigated at least twice per week. The main reason why Chinese cabbage and many other leafy vegetable crops require frequent irrigation to produce optimally is that leaf production is a function of cell expansion, which is among the plant physiological processes that are most sensitive to water stress (Hsiao, 1973; Costa., et al. 2007). The sensitivity of leaf production of Chinese cabbage to water stress is probably exacerbated by its shallow root system. Opeña., et al. (1988) found that more than $90 \%$ of the roots of mature vegetative Chinese cabbage plants occurred in the zone of soil that extended $35 \mathrm{~cm}$ deep and $20 \mathrm{~cm}$ wide around the stem.

\section{Production of Chinese cabbage in South Africa}

The Chinese cabbage is a vital indigenized leafy vegetable in the Vhembe District of Limpopo Province, where it is primarily grown along the dry winter months, making it reliant on irrigation for its water requirements. Smallholder canal schemes are the primary locus of production of this crop in the District (Van Averbeke., et al. 2007a).

Problems affecting the growth and maximum yield of Chinese cabbage

Insect pests include flea beetles and caterpillars such as cabbage loppers and cutworms. Slugs and snails may also be a problem. Diseases include club root and rots such as damping off and bacterial soft rot. Aphids, imported cabbage worm. 
Preharvest factors that affect the Chinese cabbage (Brassica rapa)

\section{Time of harvesting}

According to Van Averbeke., et al. (2007b). It is advisable to harvest the crop at very early morning hours when the plant leaves are at full turgor and retaining sufficient amount of water on the leaves All harvesting of leaves must occur between 7 and 9 am when the leaves are at full turgor. Head of the Chinese cabbage is looser than other varieties. The inner leaves must be tender

\section{Harvesting technique}

Cut whole heads at soil level when they are compact and firm and before seed stalks form usually 50 to 80 after sowing. Complete the harvest before the arrival of freezing weather. If the first fall frost arrives before heads form, Chinese cabbage can still be harvested for greens. Storing and preserving. Chinese cabbage will keep in the vegetable compartment of the refrigerator for about 4 weeks. Chinese cabbage can be blanched and frozen for 3 to 4 months.

\section{Marketable produce}

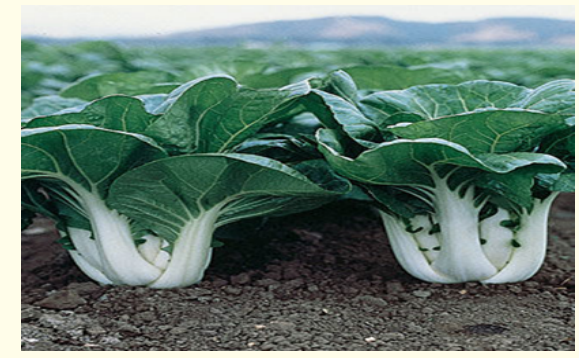

Figure 2: Chinese cabbage on the field.

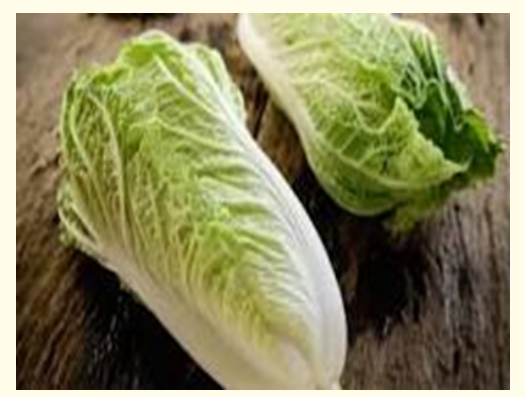

Figure 3: Chinese cabbage harvested for consumer.

\section{Materials and Methods}

Study site/area

The experiment was conducted at Tshwane University which is under DAFF (Department of Agriculture, Forestry and Fisheries) in mid-July 2019 in a controlled shade house.

\section{GPS Coordinates}

Physical address (Staartslitse Street, Gauteng, Pretoria west) Tshwane District Municipality. The GPS Coordinates are 41030,8363131996,513 PLOT:401-402 Ugagane Street.

\section{Experimental procedure}

Equipment was sterilized using sodium hypochlorite. Seeds were soaked in water after sterilization in a $100 \mathrm{ml}$ beaker for ten minutes to ensure viability and floating seeds were removed. Seeds were again soaked with a $3 \%$ of sodium hypochlorite on $100 \mathrm{ml}$ of water on a beaker for three minutes to sterilize completely. It was then rinsed three times with distilled water. Media used was vermiculite and fine bark with a ratio of 1:1 for sowing seeds. Sowing containers and trays were filled with media and watered before the sowing of seeds. Seeds were sown using a hand and covered with media then water was applied to keep media moist. Containers and trays were kept in a controlled shade house. A completely randomized block design was used, figure one shows the completely randomized block design of the six pack trays filled with the potting mix as the growth media and the seeds of Brassica rapa subsp chinensis.

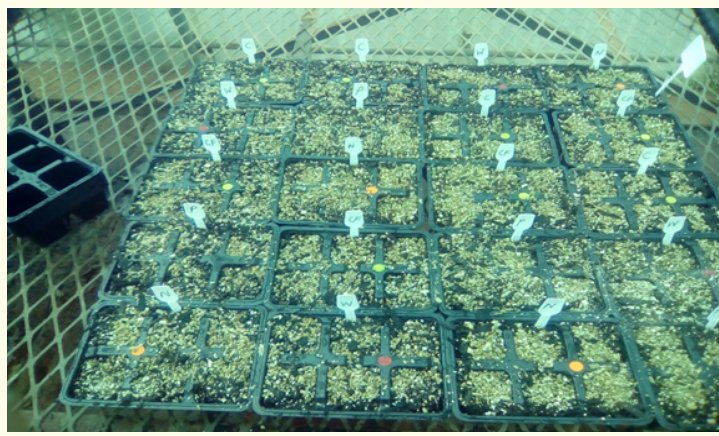

Figure 4: Chinese cabbage sown in the shade house in a completely randomized block design (Tibane M.A, May 2017).
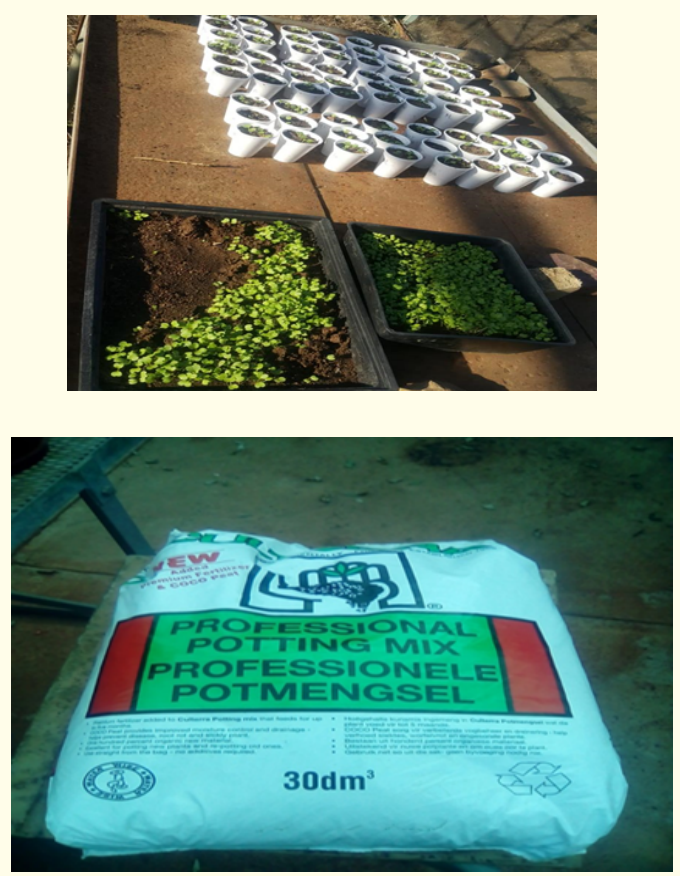

Figure 5: Chinese cabbage seed emergence between 4 -10 days after it was sown (M.A Pretoria, June 2017). The are sown for recommendation purposes in the filed. 
The emergence of seedlings was between 5- 10 days. Seedlings were kept on their containers and some of them were transplanted to the field. Fertilizers (Figure 6) were applied a after the emergence of true leaves. All mulching were applied and multifeed fertilizer was applied once a week throughout the trial.

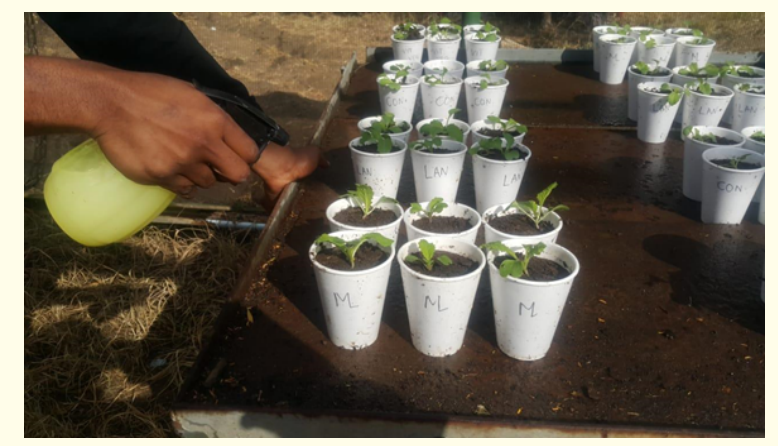

Figure 6: Application of fertilizer by foliar feeding (M.A Tibane, Pretoria westi, July 2017). Transplanted.

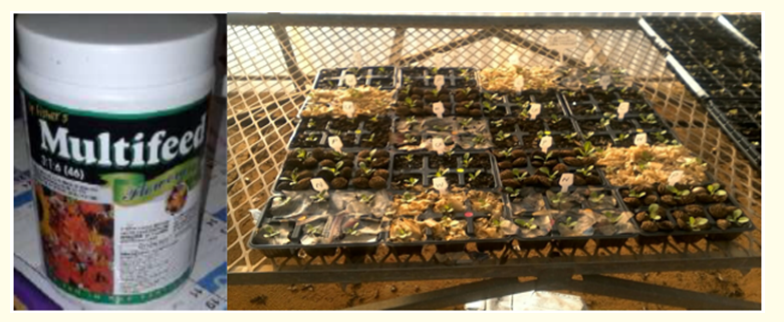

Figure 7: Four different types of organic mulching material as (M.A Tibane, pretoria West TUT, May 2019). and Multifeed.

\section{Study design}

Four treatments such as Peachpips, Newspaper, Coffee grounds Wood shavings, and control (no treatment) were used and replicated FIVE times. Experimental design used was completely randomized block design. The species of Brassica rapa subsp chinensis, four seeds per cavity tray $\mathrm{x}$ four treatments in each replicate (4seedlings $\mathrm{x} 5$ treatments $=20$ seedlings.) $\mathrm{x}$ four replicates. $=80$ Seedlings were involved in the experiment unit/ for the whole study.

\begin{tabular}{|l|c|c|c|}
\hline \multicolumn{1}{|c|}{ Control } & Control & Wood shavings & Newspaper \\
\hline $\begin{array}{l}\text { Wood } \\
\text { shavings }\end{array}$ & Peach pips & Control & Coffee grounds \\
\hline $\begin{array}{l}\text { Coffee } \\
\text { grounds }\end{array}$ & Newspaper & Coffee grounds & Control \\
\hline Peach pips & Coffee grounds & Peach pips & Wood shavings \\
\hline Newspaper & Wood shavings & Newspaper & Peach pips \\
\hline
\end{tabular}

Table 1: Completely randomized block Design of the experiment.

\section{Study population}

Each cavity contained one seedling leading to six seedlings per experimental unit and four treatments were applied and each treatment was replicated three times. Total number of seedlings used was seventy two.

\section{Data gathering}

Growth was monitored weekly and data was collected on the number of leaves per seedling, survival of the plants, damaged leaves and height $(\mathrm{cm})$ of each plant in each cavity cell. Ruler was used to collect data of the plant height $(\mathrm{cm})$.

\section{Data analysis}

TheT-test was used when statistical data was analysed.

\section{Budget and time frame}

The experiment was conducted from mid-July to first week of September allowing sowing, germination and first true leaves growth. Data was observed and harvested on the 1st week of July 2019.The cost of running the experiment included the purchase of mulching materials (Wood shavings, Peach pips, Coffee GROUNDS, Newspaper) and data sheet collection material for raw data on weekly basis (Stationery material including paper ad pen).

The TUT University was lenient enough to allow the experiment to take place without being compensated as it was beneficial for the nursery to have an experiment done on their premises. Due to the time limit the controlled experiment was harvested before its maturity stage but the researcher took an initiative to plant excess seedlings to the ground to observe the full growth of the Chinese cabbage. after September but only the experiment conducted in the shade house was quantified and presented.

The excess seedlings sown to the field forms part of observation and control to observe and evaluate the significance of fertilizers in a controlled setup compared to an open field and recommend for future researchers.

\begin{tabular}{|c|c|c|c|c|}
\hline Item & Description & Quantity & Price & Total \\
\hline 1 & MULTIFEED & 1 & R99.00 & R99.00 \\
\hline 2 & WOODSHAVINGS & 1bag & R106.00 & R106.00 \\
\hline 3 & COFFEEGROUNDS & 1bag & R78.00 & R78.00 \\
\hline 4 & NEWSPAPER & 1bag & For free & For free \\
\hline 5 & PEACHPIPS & 1bag & R78.00 & R78.00 \\
\hline 4 & $\begin{array}{c}72 \text { page exercise } \\
\text { book } \\
30 \mathrm{~cm} \text { ruler } \\
\text { Pack of ball pens }\end{array}$ & $\begin{array}{l}1 \\
1 \\
1\end{array}$ & $\begin{array}{l}\text { R5.00 } \\
\text { R2.50 } \\
\text { R11.00 }\end{array}$ & R18.50 \\
\hline 5 & $\begin{array}{c}\text { Sodium Hypocloride } \\
\text { (Jik\} }\end{array}$ & 1 & R14.00 & $\mathrm{R} 14.00$ \\
\hline 6 & Watering can & 1 & R56.00 & R56.00 \\
\hline 7 & Paper cups & 72 & R21.00 & R21.00 \\
\hline 8 & $\begin{array}{c}\text { Pocket of Brassica } \\
\text { rapa seeds }\end{array}$ & 1 & R26.00 & $\mathrm{R} 21.00$ \\
\hline 9 & Container Spray & 1 & R10.00 & R10.00 \\
\hline 10 & $\begin{array}{c}\text { Sowing trays to be } \\
\text { donated }\end{array}$ & 2 & R18.00 & R18.00 \\
\hline 11 & Potting mix & 1 bag & $\mathrm{R} 45.00$ & $\mathrm{R} 45.00$ \\
\hline 12 & Vermiculite & $5 \mathrm{~L}$ & DONATED & DONATED \\
\hline 13 & Beaker $100 \mathrm{ml}$ & 1 & R15.00 & R15.00 \\
\hline \multirow[t]{2}{*}{14} & $\begin{array}{c}\text { Pockets of Brassica } \\
\text { rapa seeds }\end{array}$ & & R26.00 & $\mathrm{R} 26.00$ \\
\hline & TOTAL & & & R591.00 \\
\hline
\end{tabular}

Table 2: Budget breakdown of the material cost needed for the experiment. 


\section{Growth parameters}

Growth was monitored weekly and data was collected on the number of leaves per seedling, survival of the plants, damaged leaves and height $(\mathrm{cm})$ of each plant in each cavity cell. Ruler was used to collect data of the plant height $(\mathrm{cm})$. At harvest number of leaves, survival rate, plant height and root length were measured to determine which fertilizers had the most suitable growth and yield.

\section{Data analysis}

ANOVA will be used when statistical data is analyzed, Tukey's test will be used to determine homogeneous groups at marketable size from the three replicates for consumer purposes and future research to be undertaken to improve the study. This is considered to be a quantitative study which is defined and According to Mouton and Marais, (1988: 155), the quantitative approach maybe described in general terms as that approach to research in the social sciences that is more highly formalized a s well a s more controlled, with a range that is more exactly defined, and which in terms of the methods used, is relatively close to the physical sciences. when compared to Filstead (as cited in Chadwick, 1984:206).

Experimental timeline Ghant chart

\begin{tabular}{|l|l|l|l|l|l|l|l|l|}
\hline \multicolumn{1}{|c|}{ Description } & W1 & W2 & W3 & W4 & W5 & W6 & W7 & W8 \\
\hline Sowing & & & & & & & & \\
\hline $\begin{array}{l}\text { Observation and } \\
\text { germination }\end{array}$ & & & & & & & & \\
\hline $\begin{array}{l}\text { Shooting of true leaves } \\
\text { and application of } \\
\text { fertilizers }\end{array}$ & & & & & & & & \\
\hline $\begin{array}{l}\text { Observation, application } \\
\text { of fertilizers and data } \\
\text { collection }\end{array}$ & & & & & & & & \\
\hline $\begin{array}{l}\text { Observation, application } \\
\text { of fertilizers and data } \\
\text { collection }\end{array}$ & & & & & & & & \\
\hline $\begin{array}{l}\text { Observation, application } \\
\text { of fertilizers and data } \\
\text { collection }\end{array}$ & & & & & & & & \\
\hline $\begin{array}{l}\text { Observation, application } \\
\text { of fertilizers and data } \\
\text { collection }\end{array}$ & & & & & & & & \\
\hline Harvesting & & & & & & & & \\
\hline
\end{tabular}

Table 3: Duration of the experiment (from 20 May to July 2017 to Harvests date of 6 July 2019).

\section{Results and Discussion}

Results

Growth after fertilization

One week after fertilization there was no much difference in leaves number between fertilizer treatments. In 1st week seedlings had an average number of four leaves from each treatment In second week seedlings applied with peach pips treatment had high number of leaves followed by wood shavings seedlings. Newspaper seedlings and coffee grounds seedlings had highest average number of leaves in third week followed by, however coffee grounds had lowest average number of leaves in the third week. On the 4th week peach pips and wood shavings achieved the highest number of leaves whereas control and coffee grounds had the lowest but not differently significant from each other (Figure 8-10).

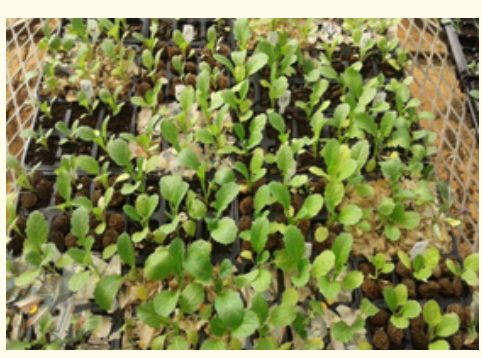

Figure 8: Harvest of Chinese cabbage during early hours (M.A Tibane, Pretoria westi, September 2017).

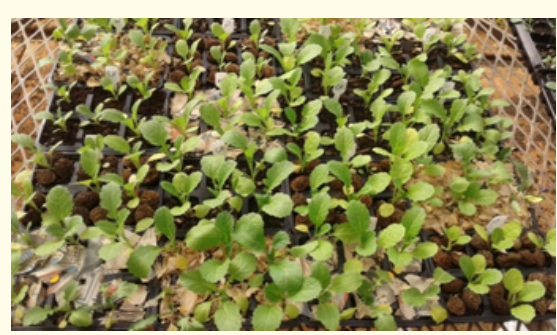

Figure 9: Chinese cabbage full layout experimental unit at harvest (M.A Tibane, Pretoria westi, September 2019.

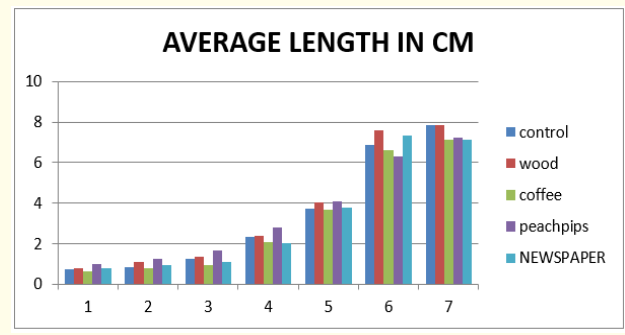

Figure 10: Average leaf number of Brassica rapa subsp. Chinensis over weeks.

The results indicate that from the first week after true leaves emerged and the fertilizer application was commenced, all treatments had the approximate same number of leaves. On the second week treatments had a slight difference on the number of leaves and the peach pips seemed to achieved more leaf growth but not significantly different from the wood shavings and the coffee, similar to the third week but noticeably the Peachpips had a slight increase or rather a stagnant growth average number of leaves while all other treatments remained on a similar average number of leaves. On the $4^{\text {th }}$ week Peach pips showed a higher significant growth followed by the Woodshavings and the control and wood shavings had a noticeable growth while the newspaper had the number of leaves (This could be an assumption for the need of more nutrients at this stage). On the fifth week Multifeed showed highest growth but not significantly different from Coffee grounds, newspaper and the control. On the $6^{\text {th }}$ week at which the harvest took place coffee grounds achieved the highest number of leaves at harvest but no significant different from the fertilizer and the control as they achieved same number of leaves at harvest.

Plant growth (height) from Multifeed, control and newspaper, coffee ground sr treatments continuously increased until the day 


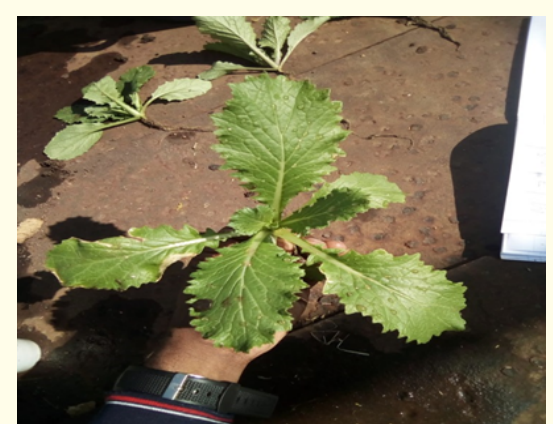

Figure 11: Chinese cabbage leaf at harvest (M.A Tibane, Pretoria, July 2017).

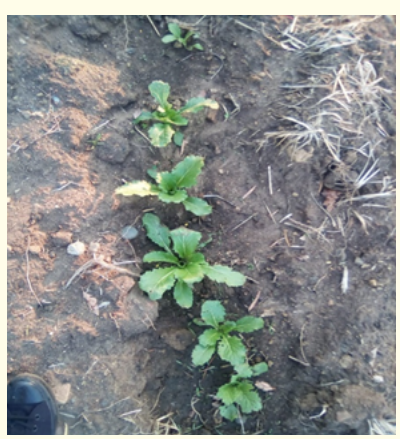

Figure 12: Brassica rapa subsp Chinensis planted on the field (M.A Tibane, Pretoria westi, Julyr 2017).
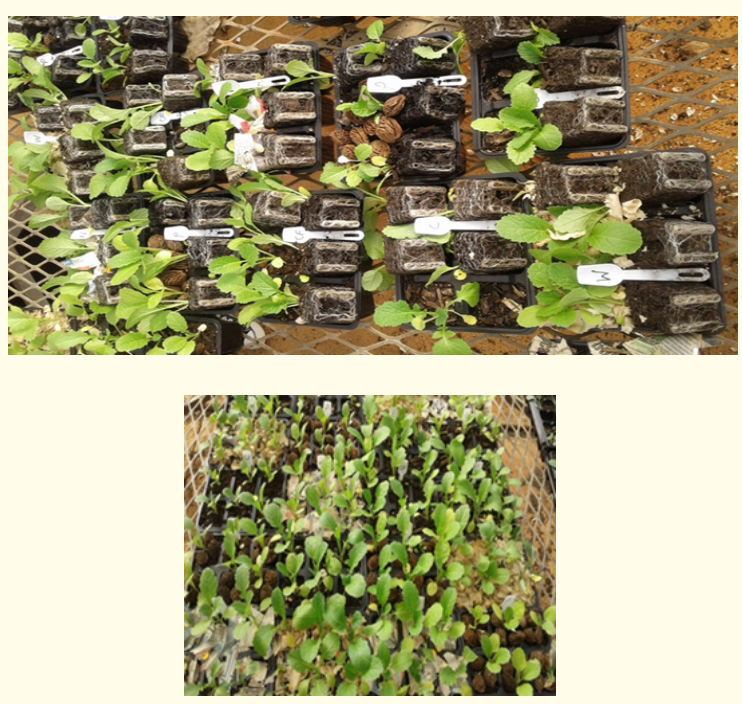

Figure 13

of harvest. However plant growth (height) from Vita veg seedlings on the $2^{\text {nd }}$ remained constant. After the third week growth of plant increased until harvest time. Multifeed had the tallest plants at harvest, while coffeegrounds had the shortest plants (Figure 14).

Number of Leaves at harvest

Seedlings applied with Peachpips and woodshavings treatments had the same average number of leave at harvest, but they were not significantly different from control and newspaper treatments. However the control had the smallest average number of leaves but it was not significantly different from other treatments (Figure 7).

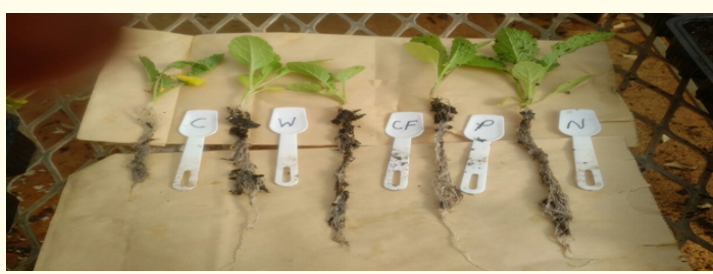

Figure 14: Comparison of Brassica rapa subsp. Chinensis plant height from different fertilizer treatments at harvest time.

Plant height at harvest

There was no significant difference in plant height at harvest between control and any of other fertilizer treatments (Figure 15). Plants from coffee grounds treatment were however significantly shorter than plants from the newspaper, control, peach pips treatment but were not significantly shorter from coffee grounds and Control treatment.

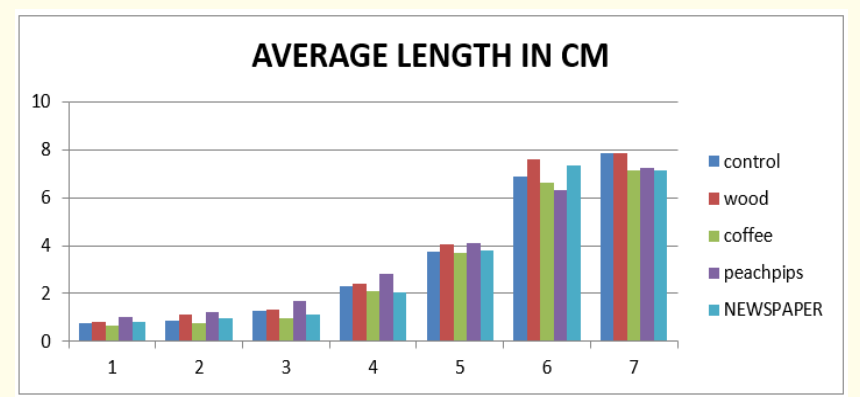

Figure 15: Plant heights of Brassica rapa subsp. Chinensis at harvest from different mulching treatments.

Root length and quality at harvest

Seedlings mulched with wood shavings had the longest roots length and it was significantly different from other treatments. Seedlings fertilised with Peachpips and newsaper had shortest roots but they were not significantly different from seedlings that were not mulched (Control).

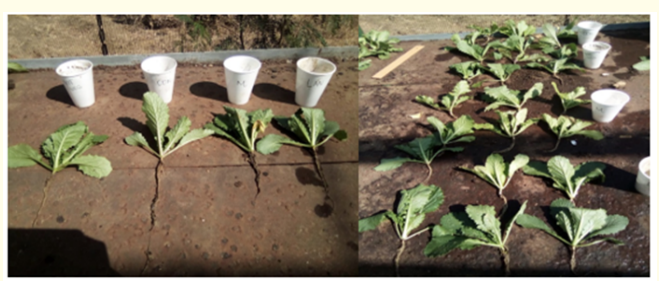

Figure 16: Root lengths of Brassica rapa subsp. Chinensis at harvest.

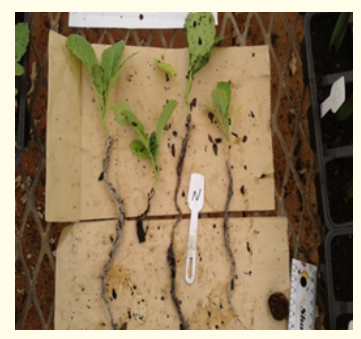

Figure 17: Root length selected from each treatment randomly. (M. A Tibane, September 2017). 


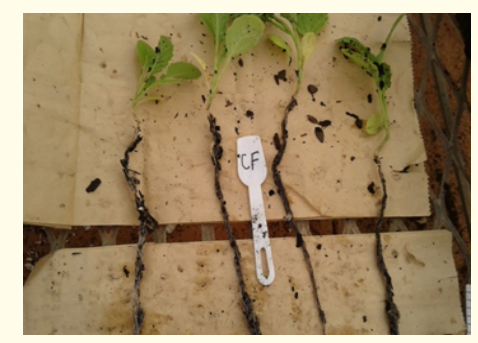

Figure 18: Replicate two showing the root length of all treatments. (M. A Tibane, Pretoria westi, September 2019).

\section{Discussion}

The results of this experiment show that seedlings with no treatment (control) had least values of growth (number of leaves and plant height). According to Mohammed and Solaiman [18] low growth of seedlings without treatment (control) result as an initial low soil nutrients. However, seedlings with control treatment had long roots than seedlings applied with peach pip, newspaper and wood shavings and coffee grounds although there were no significant difference between the treatments.

Growth started well in the peach pips treatment followed by the newspaper, this could be the fact that the peach pips were big in size and covered more surface then other mulching material. There was no significant during the first weeks of growing in all treatments in terms of number of leaves and length, But there was great variation when you look at the plants on the outer boundary of the set up compared to the other treatments which are at the center the leaves and length of the plant were much higher, the leaf size was greater and more healthier because of the randomization setup.

Seedlings applied with Multifeed (3:1:6) resulted with good plant growth (number of leaves and plant height), where $\mathrm{N}$ from both treatment resulted with high elements than $P$ which improves growth of the leaves and $\mathrm{K}$ also has high elements which improves the overall growth of the plants. Seedlings applied with) resulted with long roots than other treatments, which could be caused by high $\mathrm{P}$ element which stimulate the roots growth. The harvesting was done on week number seven, the number of leaves was ranging between 5-7 the most and at that stage the length was at 10.511 highest with the lowest $6 \mathrm{~cm}$ length.

According to Abey., et al. [19], the least growth response of Chinese cabbage obtained in this study from unfertilized seedlings (Control) might be caused by low nutrients availability during the growing period. Again Abey., et al. [19] stated that vegetables crop performance could be linked to both genetic and environmental influences amongst which is nutrient source, climatic condition, soil fertility status etc.

According to Akanbi., et al. [20], the highest plant growth resulted at organic fertilizer application may be associated with the fact that organic manure (Vita veg) releases considerable amount of nutrients for plant use. It is essential for the formation of required molecules such as chlorophyll and protoplasm formation [21-27].

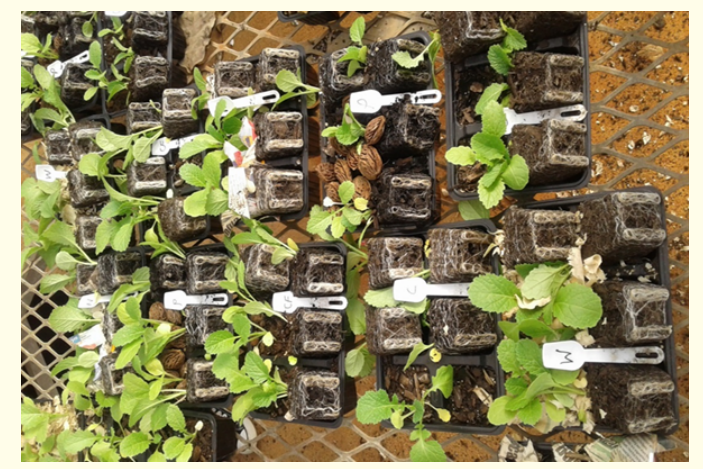

Figure 19: Showing moisture on the growth media in the replicate setups before washing of the media to measure the root length.

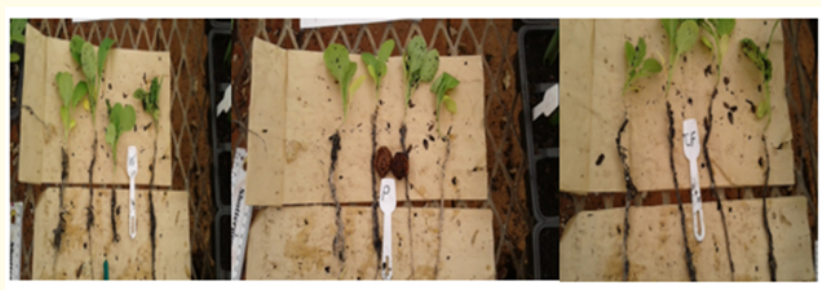

Figure 20: Variation in root length of wood shavings in four replicates and peach pips randomly selected from the four plant that were observed in the four replicates.

\section{Recommendations and Conclusion}

\section{Recommendations}

The experiment shows that all the mulching treatments had an effect on growth of Brassica rapa subsp. Chinensis producing the highest number of leaves, plant height and root length as compared to control (no treatments). It is recommended that soil analysis must be done before adding fertilizer treatments and after harvesting to determine if the fertilizer treatments added any nutrients to the medium. Due to time constraints the plants could not be left to reach maturity to determine growth and this should be done to investigate further growth effects by extending the trial time on the field.

Harvesting must be done during early hours of the day (6-8 am while plants are at full turgor). Improve the irrigation application method to allow better control over the same amount of water and scale of measurement of each fertilizer program. The use of mulches can be considered in order to conserve moisture to avoid over frequent irrigation or application of water. More replicates must be done to validate the results obtained. During the experiment some of the seedlings were also transplanted to the field while the control was kept in the shade house for the observation during the trial of six weeks.

Evidence revealed that there is significant difference between the application of mulches and kept at controlled environment compared to using natural field soil under natural weather conditions as (Figure 22) shows the Chinese Cabbage grown on the field and it showed amazing results as the seedlings were planted at a partial shade and they showed more growth before harvest- 
ing of the controlled experiment took place but only environmental growing conditions can be suggested. Plants under the shade took a longer time to grow compared to plants that were exposed to the full sun or partial sun side. The use of soilless media can be or soilless cultivation towards the use of hydroponics system to avoid nutrient loss and protect the environment by minimizing the use of fertilizer on the soil. However plants grown in plastic bags (Figure 21) under shade net cloth also shown more growth by the time of the controlled experiment was harvested this helps for future recommendations for any smallholder farmers to propagate the Chinese cabbage.

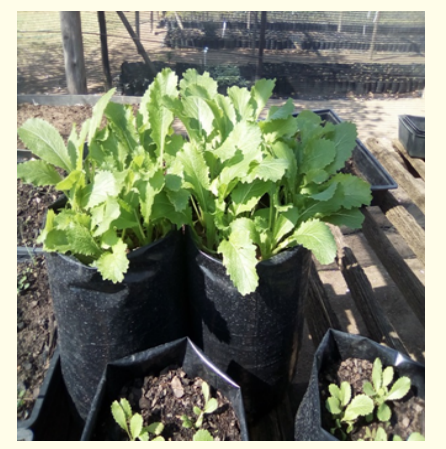

Figure 21: Chinese cabbage grown under black shade net to observe different growth environment (M.A Tibanei, Pretoria, September 2017).

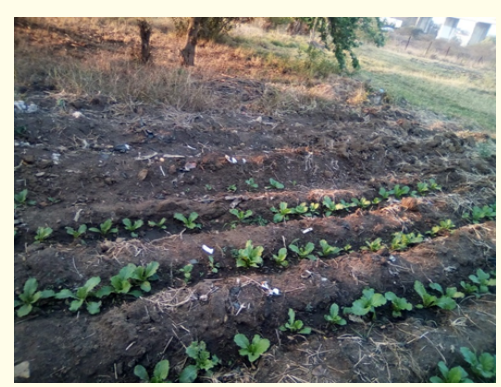

Figure 22: Chinese cabbage grown on the field to continue growth to observe in full maturity. (MA Pretoria, Pretoria,

September 2019).

\section{Conclusion}

By using a different growth media production levels or yields of the Chinese cabbage can be maximized as suggested on the recommendations. In short summary, all replicates during harvest the following observation were obtained.

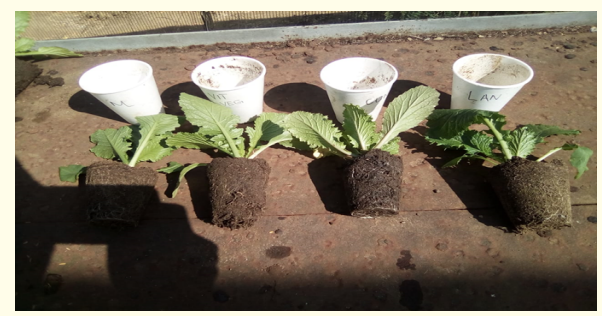

Figure 23: Seedlings of Chinese cabbage randomly selected to observes the water retention ability in the growth media from the four treatments, in the three replicates (M.A TIBANE, Pretoria west, July 2017)
It is recommended for future studies that a soil detector machine be used when harvesting the plant to determine the moisture content, in the growth media of each type of treatment. Also Place around extra plants around the replicates to protect them from wilting to get correct data on number of leaves.

Also it is recommended that in the future one can use river sand instead of potting mix to be able to count the number of roots because it was very difficult to count and wash the media out of the roots to count, due to this factor number of roots could not be counted.

Soil analysis must be done before adding the mulching treatments and after harvesting the plant.

One can conclude with a statement that to achieve maximum yield of the Chinese cabbage one can use the Vita Veg fertilizer and multifeed to grow and produce the Chinese cabbage but they had no significant difference compared to the control in the number of leaves.

\section{Bibliography}

1. RAKOW G. "Species origin and economic importance of Brassica". Biotechnology in Agriculture and Forestry 54 (2004): 3-11.

2. Department of Agriculture, Forestry and Fisheries. Chinese cabbage, Production guidelines. Republic of South Africa 2 (2013): 3 .

3. HENDRICKS L. Flora of China, edible crops. 72 (1999): 198213.

4. TSUNODA S., et al. "The wild forms of the Brassica oleracea group $(2 n=18)$ and their possible relations to the cultivated ones". In: Brassica crops and wild allies, biology and breeding. Japan Scientific Societies Press, Tokyo (1980): 121-132.

5. DUKE N. “Cultivation of edible crops”. Flora of China 25 (1983): 975-981.

6. MANRIQUE LA. "Greenhouse crops: A review". Journal Plant Nutritional 16 (1993): 2411-2477.

7. ARTEMYEVA AM and SOLOVYEVA AE. "Quality evaluation of some cultivar types of leafy Brassica rapa". Acta Horticulturae 706 (2006): 28-121.

8. LARKCOM J. “Oriental vegetables”. Tokyo, Japan: Kodansha International Ltd (2008).

9. HILL DE. "Chinese cabbage and Pak Choi Trials 1988-1989”. Bulletin 879. The Connecticut Agricultural Experiment station, New Haven, USA 12 (1990).

10. INDREA D., et al. "Vegetable crops". Ed. Bucureşti, Romania: CERES 43 (2014): 42-49.

11. KREẐEL J and KOLOTA E. "The effects of nitrogen fertilization on yielding and biological value of Chinese cabbage grown from seedlings for autumn harvest". Journal of Elementology 13 (2008): 60-255. 
12. TOXOPEUS H and BAAS J. "Brassica rapa L". In: Grubben GJH and Denton OA (eds.) PROTA 2: vegetables/legumes [CDRom]. PROTA, Wageningen, The Netherlands (2004): 146-151.

13. FAO. Traditional Food Plant. Food and Agricultural Organization of the United Nations, Rome, Italy (1988).

14. DENG SY., et al. "In vitro propagation of Chinese cabbage". Plant Cell, Tissue and Organ Culture 26 (1991): 135-139.

15. TSHIKALANGE TE and VAN AVERBEKE W. "The cultivation of Brassica rapa L. subsp Chinensis in Vhembe, Limpopo Province, South Africa". In: Proc. Int. symp. On the nutritional value and water use of indigenous crops for improved livelihoods (2006): 19-20.

16. DUKE JA. "The quest for tolerant germaplasm. p. 1-6". In: ASA Special Symposium 32, Crop tolerance to suboptimal land conditions. American Society of Agronomy. Madison, WI. 15 (1978): 1-61.

17. COOKE GW. "Fertilizing for Maximum Yield". Granada Plublishing Ltd. 3rd edition (1975): 74-103.

18. MOHAMMED., et al. "Efficacy of organic and nonorganic fertilizer on the growth of cabbage (Brassica oleraceae L)". International Journal of Agricultural Crop Science 4 (2012): 128-138.

19. ABEY I., et al. "Genotype, sulphur and nutrition and soil types effect on growth and dry matter production of spring onion". Journal of Horticultural Science and Technology 77 (2002): 340-345.

20. AKANBI WB., et al. "Growth, herbage and seed yield and quality of Telfaria occidentalis as influenced by cassava peel compost and mineral fertilizer". World Journal of Agricultural Science 3 (2007): 508-516

21. LAKER MC. "Introduction to the special edition of Water SA on indigenous crops, water and human nutrition". Water SA 33 (2007): 3 .

22. LIWAYWAY H. Acero is with the Department of Science, College of Arts and Science, San Beda College, Mendiola, Manila Philippines 4 (2013): 337.

23. MOYIN-JESU EI. "Determination of soil nutrients levels for maximum yield of okra using sole and amended plant residues". Journal of Tropical Agricultural Science 31 (2008): 233245.

24. OLAYINI JO and OJETAYO AE. "Effect of fertilizer types on the growth and yield of two cabbage varieties". Journal of Animal and Plant Sciences 12 (2011): 1573-1582.

25. SCHEFFLER JA and DALE PJ. “Opportunities for gene transfer from transgenic oilseed rape (Brassica napus) to related species". Transgenic Research 3 (1994): 263-278.
26. SHARMA DK and KUMAR A. "Effect of nitrogen fertilisers under different irrigation scheduling on production potential and economics of mustard". Fertiliser News 37 (1992): 37-43.

27. Tetsuo Hara and Yoji Sonoda. "Cabbage-head development as affected by nitrogen and temperature". Soil Science and Plant Nutrition 28 (1982): 109-117.

\section{Volume 3 Issue 11 November 2019}

(c) All rights are reserved by Tibane Meluleki Adrian. 